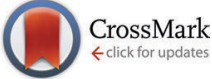

Cite this: Phys. Chem. Chem. Phys., $2016,18,30770$

Received 28th August 2016, Accepted 18th October 2016 DOI: $10.1039 / c 6 c p 05944 a$ www.rsc.org/pccp

\title{
A new sodiation-desodiation mechanism of the titania-based negative electrode for sodium-ion batteries $\dagger$
}

\author{
Changsheng Ding, ${ }^{a}$ Toshiyuki Nohira* ${ }^{\mathrm{b}}$ and Rika Hagiwara*a
}

\begin{abstract}
$\mathrm{TiO}_{2}$ is widely investigated as a negative electrode for lithium-ion batteries. In sodium-ion batteries, however, the sodiation-desodiation mechanism of $\mathrm{TiO}_{2}$ is still unclear. Here, we report a new sodiationdesodiation mechanism for an anatase $\mathrm{TiO}_{2} / \mathrm{C}$ electrode in an ionic liquid electrolyte at $90{ }^{\circ} \mathrm{C}$, where it shows a high reversible capacity of $278 \mathrm{~mA} \mathrm{~h} \mathrm{~g}^{-1}$. During the first charge process, $\mathrm{TiO}_{2}$ reacts with $\mathrm{Na}$ ions to form a $\mathrm{Na}_{2} \mathrm{Ti}^{\mathrm{l}} \mathrm{Ti}^{\mathrm{lV}} \mathrm{O}_{4}$ solid solution. During the first discharge process, the solid solution converts into a mixture of $\mathrm{TiO}_{2}, \mathrm{Na}_{2} \mathrm{TiO}_{3}$, and $\mathrm{TiO}$, with the former two being X-ray amorphous. In the subsequent cycle, the mixture acts as the active material, reversibly reacting with $\mathrm{Na}$ ions to re-form the $\mathrm{Na}_{2} \mathrm{Ti}^{\mathrm{I}} \mathrm{Ti}^{\mathrm{IV}} \mathrm{O}_{4}$ solid solution. This mechanism, which has not been reported for $\mathrm{Na}$ or $\mathrm{Li}$ ion insertion-extraction in anatase $\mathrm{TiO}_{2}$, can help understand this promising electrode material and develop safe sodium-ion batteries with high energy density.
\end{abstract}

\section{Introduction}

Rechargeable sodium batteries are attracting much attention as a replacement for rechargeable lithium batteries in large-scale applications such as electric vehicles and stationary energy storage devices, because sodium is a much more abundant and widely available resource than lithium. Many promising positive electrode materials have been developed for rechargeable sodium-ion batteries, such as $\mathrm{Na}_{x}\left[\mathrm{Fe}_{1 / 2} \mathrm{Mn}_{1 / 2}\right] \mathrm{O}_{2},{ }^{1} \mathrm{Na}_{0.44} \mathrm{MnO}_{2},{ }^{2}$ $\beta-\mathrm{NaMnO}_{2},{ }^{3} \mathrm{NaCrO}_{2},{ }^{4} \mathrm{Na}_{2} \mathrm{FeP}_{2} \mathrm{O}_{7}{ }^{5}{ }^{5} \mathrm{Na}_{3} \mathrm{~V}_{2}\left(\mathrm{PO}_{4}\right)_{3},{ }^{6}$ and $\mathrm{NaFePO}_{4}{ }^{7}$ However, only a few materials are available for negative electrodes, such as alloys, ${ }^{8,9}$ hard carbon, ${ }^{10}$ and sodium titanium oxides. ${ }^{11,12}$ $\mathrm{TiO}_{2}$, which is used as an alternative negative electrode material to graphite in rechargeable lithium batteries, was recently investigated for rechargeable sodium batteries. Specifically, amorphous $\mathrm{TiO}_{2}{ }^{13}$ anatase $\mathrm{TiO}_{2},{ }^{14-17} \mathrm{TiO}_{2}(\mathrm{~B}),{ }^{18} \mathrm{TiO}_{2}(\mathrm{H}),{ }^{19}$ and Nb-doped rutile $\mathrm{TiO}_{2}{ }^{20}$ have been reported as potential negative electrode materials for rechargeable sodium batteries using organic electrolytes. Among them, anatase $\mathrm{TiO}_{2}$ exhibits the best charge-discharge properties. In our previous study, we showed that nanoscale carbon-coated anatase $\mathrm{TiO}_{2}\left(\mathrm{TiO}_{2} / \mathrm{C}\right)$ has high reversible capacity,

\footnotetext{
${ }^{a}$ Graduate School of Energy Science, Kyoto University, Sakyo-ku, Kyoto 606-8501, Japan. E-mail: hagiwara@energy.kyoto-u.ac.jp; Fax: +81-75-753-5906; Tel: +81-75-753-5822

${ }^{b}$ Institute of Advanced Energy, Kyoto University, Uji 611-0011, Japan. E-mail: nohira.toshiyuki.8r@kyoto-u.ac.jp

$\dagger$ Electronic supplementary information (ESI) available. See DOI: 10.1039/ с6ср05944a
}

high rate capability, and excellent cycle stability in an ionic liquid electrolyte at $90{ }^{\circ} \mathrm{C} .{ }^{21}$

However, the corresponding sodiation-desodiation mechanisms in $\mathrm{TiO}_{2}$-based electrodes remain unclear. In the lithium battery system, the insertion of $\mathrm{Li}$ into anatase $\mathrm{TiO}_{2}$ forms orthorhombic $\mathrm{Li}_{0.5} \mathrm{TiO}_{2} \cdot{ }^{22-27}$ Yet no orthorhombic $\mathrm{Na}_{0.5} \mathrm{TiO}_{2}$ has been observed in rechargeable sodium batteries. ${ }^{15,28} \mathrm{Kim}$ et al. reported that the anatase $\mathrm{TiO}_{2}$ structure was maintained during the $\mathrm{Na}$ ion insertion-extraction cycles, and suggested that $\mathrm{Na}$ ions would be reversibly inserted into the anatase lattice following the reversible $\mathrm{Ti}^{4+} / \mathrm{Ti}^{3+}$ redox reaction. ${ }^{15}$ In contrast, Wu et al. showed that the anatase $\mathrm{TiO}_{2}$ structure completely vanished after $\mathrm{Na}$ ion insertion and did not reappear during $\mathrm{Na}$ ion extraction. ${ }^{28}$ Their proposed reaction mechanism includes the formation of sodium titanate phase, metallic titanium, sodium superoxide, and oxygen. They also suggested that the newly formed amorphous sodium titanate phase was able to reversibly insert/extract about 0.41 sodium ion per $\mathrm{TiO}_{2}$. However, the composition of the formed amorphous sodium titanate phase was unclear. These sodiationdesodiation mechanisms were based on organic electrolytes at room temperature, and therefore, they may not be applicable to the anatase $\mathrm{TiO}_{2} / \mathrm{C}$ electrode in an ionic liquid electrolyte at $90{ }^{\circ} \mathrm{C}$, where it shows high reversible capacity. Here, we investigated the sodiation-desodiation of the $\mathrm{TiO}_{2} / \mathrm{C}$ electrode in the $\mathrm{Na}[\mathrm{FSA}]-$ $\left[\mathrm{C}_{3} \mathrm{C}_{1}\right.$ pyrrr][FSA] (FSA = bis(fluorosulfonyl)amide; $\mathrm{C}_{3} \mathrm{C}_{1}$ pyrr = $N$-methyl- $N$-propylpyrrolidinium) ionic liquid electrolyte at $90{ }^{\circ} \mathrm{C}$. The results revealed a new sodiation-desodiation mechanism, which is different from any other mechanism reported so far for $\mathrm{Li}$ or $\mathrm{Na}$ ion insertion-extraction in anatase $\mathrm{TiO}_{2}$. 


\section{Experimental}

Commercial anatase $\mathrm{TiO}_{2}$ nanoparticles (Sigma Aldrich) and citric acid (Sigma Aldrich) were mixed and heated under $\mathrm{Ar}$ atmosphere at $600{ }^{\circ} \mathrm{C}$ for $12 \mathrm{~h}$ to prepare $\mathrm{TiO}_{2} / \mathrm{C}$ nanoparticles. The nanoparticles were 50-100 $\mathrm{nm}$ in size, and contained approximately 3 wt $\%$ carbon. The working electrodes were fabricated by a conventional coating method. A slurry consisting of $\mathrm{TiO}_{2} / \mathrm{C}$ (80 wt\%), graphite (15 wt\%), and polyamide-imide (5 wt\%) in $\mathrm{N}$-methyl-2-pyrrolidone (NMP) was uniformly spread onto an $\mathrm{Al}$ foil. The electrodes were dried in vacuo at $120{ }^{\circ} \mathrm{C}$ overnight, before transfer into an Ar-filled glovebox. The charge-discharge tests were performed using coin-type 2032 cells, with a sodium foil as the counter electrode. A mixture of $\mathrm{Na}[\mathrm{FSA}]-\left[\mathrm{C}_{3} \mathrm{C}_{1}\right.$ pyrr $][\mathrm{FSA}]$ ionic liquids with the molar ratio of $2: 8$ was used as the electrolyte. A glass fibre filter (Whatman, GF-A, $260 \mathrm{~mm}$ ) was used as a separator. The working electrode and separator were vacuum-impregnated with the ionic liquid electrolyte at $60{ }^{\circ} \mathrm{C}$ before assembling the cells.

The cells were charged/discharged by $\mathrm{CC}$ or CC-CV modes at $90{ }^{\circ} \mathrm{C}$, with current rates of $2-1000 \mathrm{~mA} \mathrm{~g}^{-1}$, in the voltage range of 0.01-2.5 V. After the charging and discharging tests, the $\mathrm{TiO}_{2} / \mathrm{C}$ electrodes were removed from the cells and were washed by anhydrous tetrahydrofuran (THF; Wako Pure Chemicals, water content $<10 \mathrm{ppm}$ ) in the Ar-filled glovebox to remove the electrolyte. The crystal structure of the $\mathrm{TiO}_{2} / \mathrm{C}$ electrodes was analyzed by X-ray diffraction (Rigaku SmartLab), during which, the electrodes were sealed in an airtight sample holder in the Ar-filled glovebox to avoid air exposure. The morphologies of the $\mathrm{TiO}_{2} / \mathrm{C}$ electrodes were investigated by field emission scanning electron microscopy (FE-SEM; Hitachi SU8000) with EDX analysis. For all the SEM observations too, the electrodes were sealed in an airtight sample holder in the Ar-filled glovebox. For TEM (Hitachi HF2000) including electron diffraction and EDX study, the $\mathrm{TiO}_{2} / \mathrm{C}$ electrodes were prepared by focused ion beam (FIB) and placed on a copper grid in an argon-filled glovebox.

\section{Results and discussion}

The charge-discharge curves in the first cycle for the anatase $\mathrm{TiO}_{2} / \mathrm{C}$ electrode at the current rates of $2-1000 \mathrm{~mA} \mathrm{~g}^{-1}$ are shown in Fig. 1a. The charge-discharge was conducted in the constant current (CC) mode, which will be used in subsequent tests unless indicated otherwise. For current rates below $100 \mathrm{~mA} \mathrm{~g}^{-1}$, there were two distinct voltage plateaus at above $1.5 \mathrm{~V}$ and below $0.4 \mathrm{~V}$ in the charge process (sodiation). When the rate was increased to $1000 \mathrm{~mA} \mathrm{~g}^{-1}$, the plateaus disappeared. The voltage plateau above $1.5 \mathrm{~V}$ is related to side reactions, including the reduction of the FSA anion and the formation of a solid-electrolyte interphase (SEI). ${ }^{21}$ The other voltage plateau below $0.4 \mathrm{~V}$ is attributable to the sodiation of $\mathrm{TiO}_{2} / \mathrm{C}$. Meanwhile, there was no voltage plateau in the discharge process (desodiation). Fig. 1b shows the charge, discharge, and irreversible capacities at different current rates. The $\mathrm{TiO}_{2} / \mathrm{C}$ electrode showed a reversible capacity of $278 \mathrm{~mA} \mathrm{~h} \mathrm{~g}{ }^{-1}$. The charge capacity decreased rapidly with increasing charge-discharge rate. The discharge capacity remained almost the same at (a)

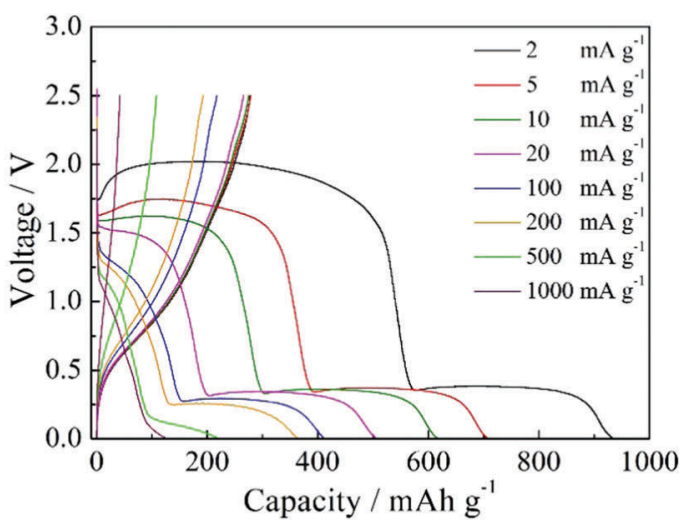

(b)

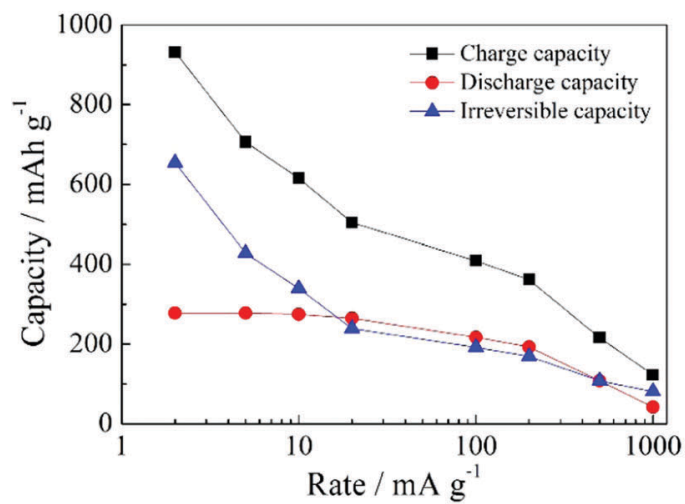

(c)

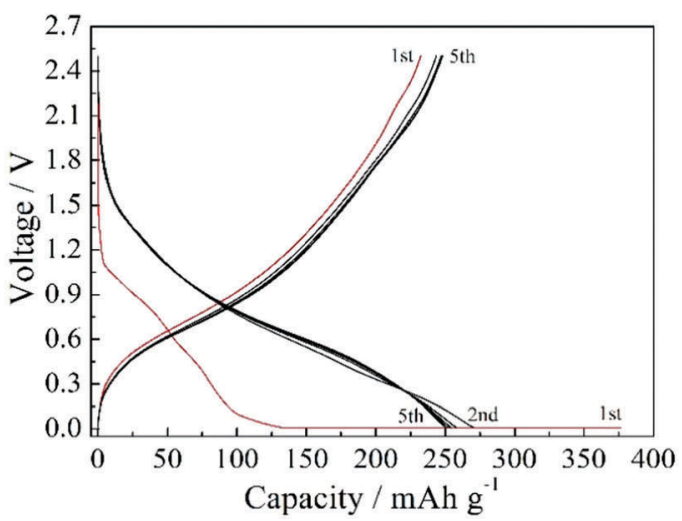

Fig. 1 Charge-discharge performance of the $\mathrm{TiO}_{2} / \mathrm{C}$ electrode: (a) chargedischarge curves in the first cycle at different current rates, (b) relationship between the current rates and capacities in the first cycle, and (c) chargedischarge curves in the $\mathrm{CC}-\mathrm{CV}$ charge mode and subsequent CC chargedischarge mode.

2-20 $\mathrm{mA} \mathrm{g}^{-1}$, and decreased at higher charge-discharge rates. The irreversible capacity also decreased drastically with increasing charge-discharge rate. The irreversible capacity can be effectively reduced without losing the discharge capacity, by applying the constant current-constant voltage (CC-CV) charge mode. Fig. 1c shows the charge-discharge curves by means of $\mathrm{CC}-\mathrm{CV}$ charge (CC: $1000 \mathrm{~mA} \mathrm{~g}^{-1}$ to $0.01 \mathrm{~V}$; CV: $0.01 \mathrm{~V}$ with $20 \mathrm{~mA} \mathrm{~g}^{-1}$ cut-off current), CC discharge ( $\left.20 \mathrm{~mA} \mathrm{~g}^{-1}\right)$, and subsequent CC chargedischarge $\left(20 \mathrm{~mA} \mathrm{~g}^{-1}\right)$. In the first cycle, the irreversible capacity is $144 \mathrm{~mA} \mathrm{~h} \mathrm{~g}^{-1}$, which is considerably lower than that obtained by the CC mode at $20 \mathrm{~mA} \mathrm{~g}^{-1}$ (239 $\mathrm{mA} \mathrm{h} \mathrm{g}^{-1}$, Fig. 1a). This means 
that the side reaction above $1.5 \mathrm{~V}$ is largely suppressed by the $\mathrm{CC}-\mathrm{CV}$ charge mode with high current rate. When the voltage is forcibly lowered below $1.5 \mathrm{~V}$ by the high current, it is presumed that another side reaction proceeds to form a favorable solid electrolyte interphase (SEI) layer on the surface of $\mathrm{TiO}_{2} / \mathrm{C}$. When the SEI layer is once formed, the side reaction above 1.5 $\mathrm{V}$ scarcely occurs in the subsequent cycles like the CC charge mode. The discharge capacity by the CC-CV mode had similar values to that obtained by the CC mode, and increased in the subsequent cycle. After five charge-discharge cycles, the discharge capacities for the $\mathrm{CC}-\mathrm{CV}$ and $\mathrm{CC}$ modes became identical.

To investigate the sodiation-desodiation of the $\mathrm{TiO}_{2} / \mathrm{C}$ electrode, ex situ X-ray diffraction (XRD) analysis was performed for the electrodes in different charge-discharge states. The chargedischarge states at $20 \mathrm{~mA} \mathrm{~g}^{-1}$ and the XRD results are shown in Fig. 2a and b, respectively. The anatase $\mathrm{TiO}_{2}$ crystal phase gradually disappeared during the charge process (sodiation). Between the as-prepared and $0.5 \mathrm{~V}$-charged electrodes ((1) and (2), respectively), there was no significant change in the XRD pattern except for the peak intensity. A new crystal phase appeared in (3) when the electrode was charged to $0.3 \mathrm{~V}$, although the anatase $\mathrm{TiO}_{2}$ crystal phase was still detectable with weak peak intensity. When the electrode was charged to $0.01 \mathrm{~V}$ in (4), the anatase $\mathrm{TiO}_{2}$ crystal phase completely vanished, and only the new crystal phase was detected. The disappearance of the anatase $\mathrm{TiO}_{2}$ crystal phase at the end of charge is in contrast with the result reported by Kim et al. ${ }^{15}$ in which the original anatase $\mathrm{TiO}_{2}$ crystal phase was maintained at the end of charge. Meanwhile, the disappearance of the anatase $\mathrm{TiO}_{2}$ crystal phase at the end of charge was reported by Wu et al. ${ }^{28}$ although they did not detect any new crystal phase.

During the discharge process, the $\mathrm{Na}$ ion is extracted from the charged $\mathrm{TiO}_{2} / \mathrm{C}$ electrode (desodiation). For the electrode discharged to $1.0 \mathrm{~V}(5)$, the diffraction peaks of the newly formed crystal phase shifted to higher angles and had lower intensities. When the electrode was discharged to $2.5 \mathrm{~V} \mathrm{(6),} \mathrm{the}$ newly formed crystal phase disappeared while there was no re-emergence of the anatase $\mathrm{TiO}_{2}$ crystal phase. When the discharged $\mathrm{TiO}_{2} / \mathrm{C}$ electrode was re-charged to $0.01 \mathrm{~V}(7)$, the new crystal phase appeared again. These results suggest that a new sodium titanate crystal phase was formed during the sodiation process, and that this process was more or less reversible during the charge-discharge cycles. Similar results were also obtained by applying the CC-CV charge mode (ESI, $\uparrow$ Fig. S1), where the new crystal phase appeared and disappeared reversibly. Thus, the application of the $\mathrm{CC}-\mathrm{CV}$ charge mode reduced the first irreversible capacity (due to the side reactions) without changing the sodiation-desodiation mechanism.

To analyze the microscopic morphological changes of the $\mathrm{TiO}_{2} / \mathrm{C}$ electrode during the charge-discharge process, ex situ scanning electron microscopy (SEM) studies were carried out with the electrode in different charge-discharge states. As shown in Fig. 3a, the pristine electrode consisted of $\mathrm{TiO}_{2} / \mathrm{C}$ nanoparticles (50-100 $\mathrm{nm}$ in size) and graphite particles (dark grey, $1-3 \mu \mathrm{m})$. When the electrode was charged to $0.5 \mathrm{~V}$, some (a)

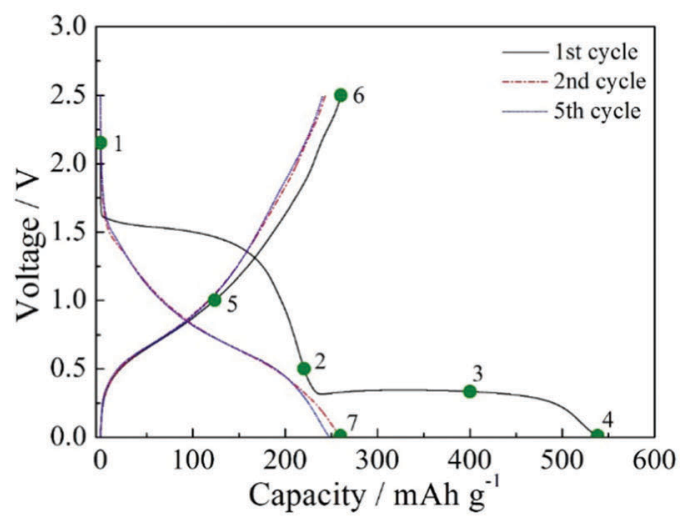

(b)

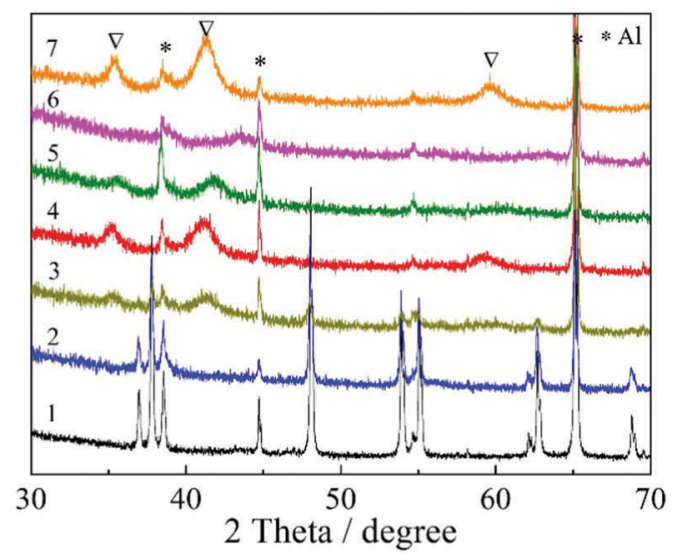

Fig. 2 Electrochemical and structural characterization of the $\mathrm{TiO}_{2} / \mathrm{C}$ electrode: (a) charge-discharge curves of the electrode at $20 \mathrm{~mA} \mathrm{~g}^{-1}$, during the first (black line), the second (red line), and the fifth (blue line) cycles, and (b) ex situ XRD patterns of the electrodes at various charge/ discharge stages: (1) pristine condition, (2) charged to $0.5 \mathrm{~V}$, (3) charged to about $0.3 \mathrm{~V}$, (4) charged to $0.01 \mathrm{~V},(5)$ discharged to $1.0 \mathrm{~V},(6)$ discharged to $2.5 \mathrm{~V}$, and (7) re-charged to $0.01 \mathrm{~V}$, as indicated in (a). The symbols of * and $\nabla$ represent Al substrate and new crystal phase, respectively.

round particles were formed on its surface (Fig. 3b). These particles grew in size upon further charging to $0.01 \mathrm{~V}$, reaching about $2 \mu \mathrm{m}$ in the fully charged state (Fig. 3c). When the CC-CV mode was applied, the formed round particles were much smaller $(c a .0 .5 \mu \mathrm{m})$ even in the fully charged state (ESI, $\dagger$ Fig. S2). Thus, it is reasonable to regard the round particles as the by-product of the reductive decomposition of electrolyte in the first charge process, and that the CC-CV charge mode can suppress their formation. When the electrode was discharged, the round particles did not disappear, but remained on the surface of the electrode (Fig. 3d and e). They were also present at the same size on the surface of the fully recharged electrode (Fig. 3f). Thus, the round particles were only formed during the first charge.

The chemical composition of the round particles was investigated with energy dispersive X-ray (EDX) analysis. EDX mapping analysis of the fully charged $\mathrm{TiO}_{2} / \mathrm{C}$ electrode shows that these particles consisted mostly of $\mathrm{Na}, \mathrm{F}, \mathrm{S}$ and $\mathrm{O}$, and no Ti was detected (ESI, $\dagger$ Fig. S3). EDX point analysis shows that the round particles were possibly composed of $\mathrm{NaF}, \mathrm{Na}_{2} \mathrm{O}$, and $\mathrm{Na}_{2} \mathrm{~S}$ 

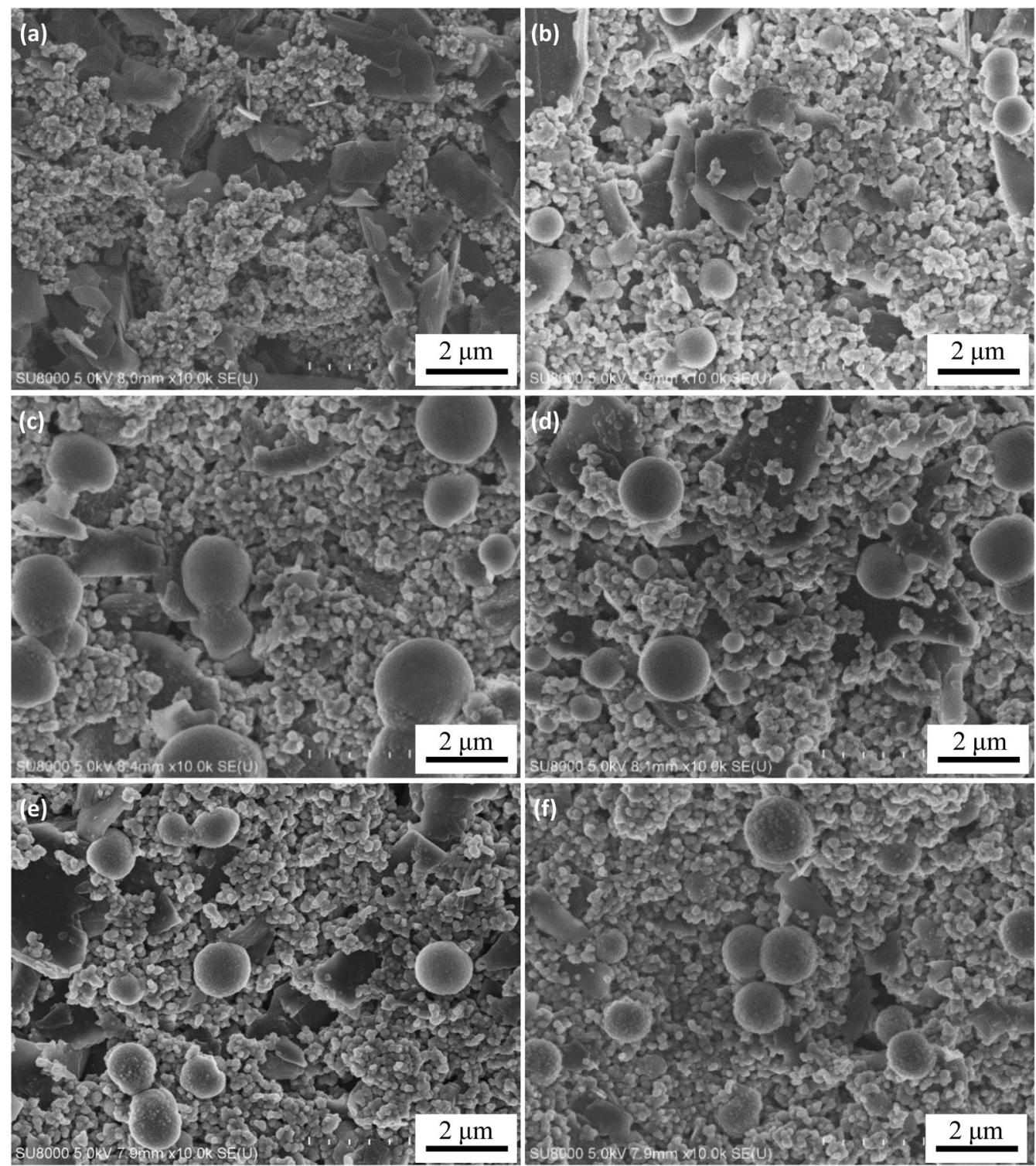

Fig. $3 \mathrm{SEM}$ images of the $\mathrm{TiO}_{2} / \mathrm{C}$ electrodes at various charge-discharge stages: (a) pristine electrode, (b) charged to $0.5 \mathrm{~V}$, (c) charged to $0.01 \mathrm{~V}$, (d) discharged to $1.0 \mathrm{~V}$, (e) discharged to $2.5 \mathrm{~V}$, and (f) re-charged to $0.01 \mathrm{~V}$.

(ESI, $\dagger$ Fig. S4), which resulted from the electrolyte reduction during the first charge process. These compounds are considered to be in the amorphous phase, since no peaks of crystalline $\mathrm{NaF}, \mathrm{Na}_{2} \mathrm{O}$, or $\mathrm{Na}_{2} \mathrm{~S}$ were detected in the XRD patterns (Fig. 2b).

Fig. 4a shows the XRD patterns of the $\mathrm{TiO}_{2} / \mathrm{C}$ electrode discharged to $2.5 \mathrm{~V}$ in the first and fifth cycles. The patterns appear identical, each with two main peaks for 200 and 220 with the $d$-values of 208.8 and $147.4 \mathrm{pm}$, respectively. These peaks are matched with the cubic TiO phase (JCPDS file No. 00-008-0117), suggesting that the TiO crystal phase was formed in the electrode discharged to $2.5 \mathrm{~V}$. The results from transmission electron microscopy (TEM) and electron diffraction also confirm the formation of the TiO crystal phase in this electrode (Fig. $4 \mathrm{~b}$ and c). The electron diffraction pattern can be completely indexed to the cubic TiO (rock salt) structure, and the calculated $d$-values are in agreement with those of the cubic TiO card
(ESI, $\dagger$ Table S1). However, EDX analysis shows that Na was also present in the $\mathrm{TiO}_{2} / \mathrm{C}$ electrode discharged to $2.5 \mathrm{~V}$ (Fig. $4 \mathrm{~d}$ ). The amount of $\mathrm{Na}$ is estimated to be $0.3 \mathrm{~mol}$ per mole of $\mathrm{TiO}_{2}$ in the $\mathrm{TiO}_{2} / \mathrm{C}$ electrode discharged to $2.5 \mathrm{~V}$ (ESI, $\dagger$ Fig. S5 and Table S2). Therefore, we estimate that amorphous titanium oxide and sodium titanate phases were also formed in the $\mathrm{TiO}_{2} / \mathrm{C}$ electrode discharged to $2.5 \mathrm{~V}$, in addition to the TiO crystal phase.

Fig. 5 shows the XRD patterns of the $\mathrm{TiO}_{2} / \mathrm{C}$ electrode charged to $0.01 \mathrm{~V}$ in the first and fifth cycles. The three main peaks $(111,200$, and 220) can be indexed as a face-centred cubic phase with a lattice constant of $a=441 \mathrm{pm}$. It is worth noting that this cubic phase closely resembles the crystal phases of cubic $\mathrm{Na}_{2} \mathrm{TiO}_{3}$ (JCPDS file No. 01-080-6123) and cubic TiO (JCPDS file No. 00-008-0117), and its lattice constant is between those of cubic $\mathrm{Na}_{2} \mathrm{TiO}_{3}$ and cubic TiO crystal phases $(a=449$ and $418 \mathrm{pm}$, respectively). Since both $\mathrm{Na}_{2} \mathrm{TiO}_{3}$ and TiO have the 
(a)

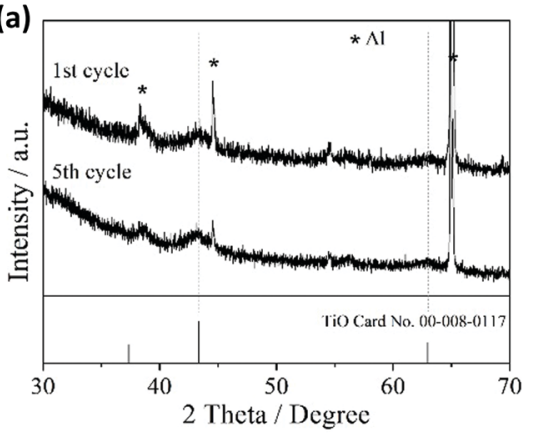

(c)

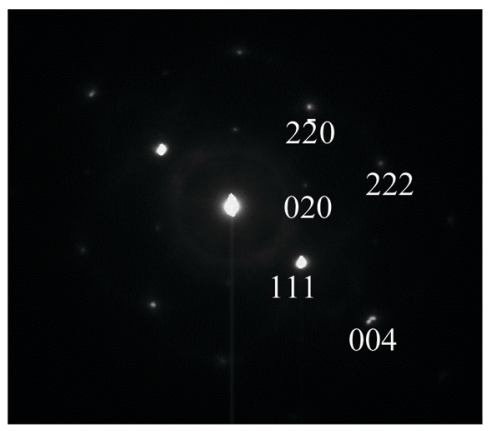

(b)

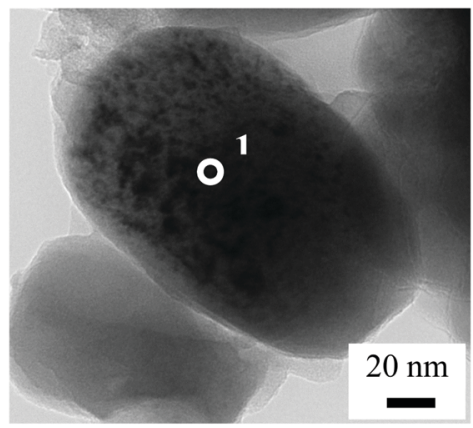

(d)

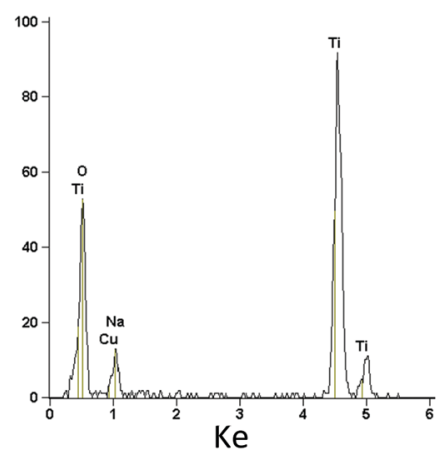

Fig. 4 Structural characterization of the $\mathrm{TiO}_{2} / \mathrm{C}$ electrode discharged to $2.5 \mathrm{~V}$ : (a) XRD patterns of the electrodes discharged to $2.5 \mathrm{~V}$ in the first and fifth cycles, (b) TEM image of the $\mathrm{TiO}_{2} / \mathrm{C}$ electrode discharged to $2.5 \mathrm{~V}$, and (c) electron diffraction pattern and (d) EDX spectrum of point 1 in (b).

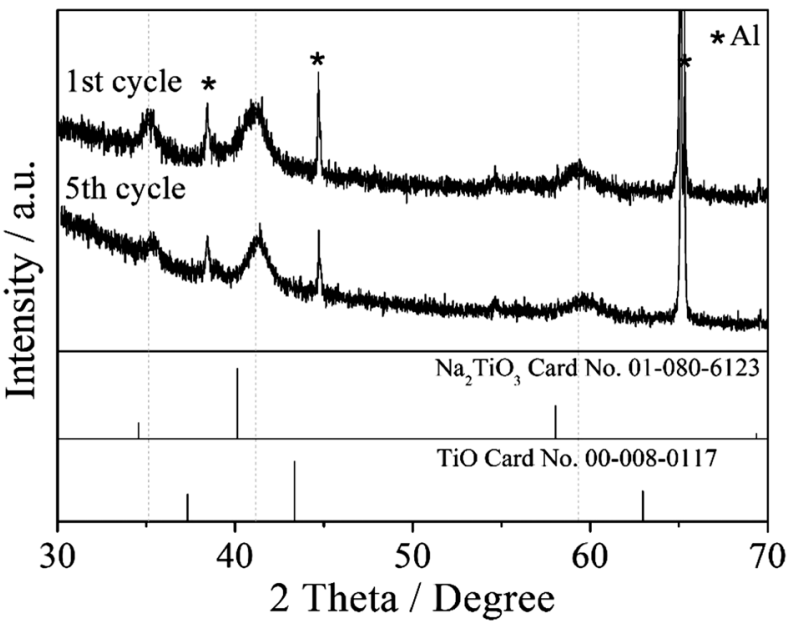

Fig. 5 XRD patterns of the $\mathrm{TiO}_{2} / \mathrm{C}$ electrode charged to $0.01 \mathrm{~V}$ in the first and fifth cycles.

rock salt structure, they are able to form a solid solution. Therefore, it is reasonable to assume that the formed new cubic crystal phase is a $\mathrm{Na}_{2} \mathrm{Ti}^{\mathrm{II}} \mathrm{Ti}^{\mathrm{IV}} \mathrm{O}_{4}$ solid solution. In order to verify this possibility, ball-milled cubic $\mathrm{Na}_{2} \mathrm{TiO}_{3}$ and TiO powders were heated at $200-600{ }^{\circ} \mathrm{C}$ in an $\mathrm{Ar}$ gas flow. Indeed, the XRD analysis of the heated powders indicates the formation of a solid solution below $500{ }^{\circ} \mathrm{C}(\mathrm{ESI}, \dagger$ Fig. S6), in which the diffraction peaks of the cubic $\mathrm{Na}_{2} \mathrm{TiO}_{3}$ phase shifted slightly to a higher angle with the dissolving of the cubic TiO phase. In Fig. S6 (ESI $\dagger$ ), some peaks other than cubic $\mathrm{Na}_{2} \mathrm{TiO}_{3}$ and cubic TiO are detected at $30-40$ degrees at the temperature above
$500{ }^{\circ} \mathrm{C}$, which is explained by the phase transition of cubic $\mathrm{Na}_{2} \mathrm{TiO}_{3}$ to monoclinic $\mathrm{Na}_{2} \mathrm{TiO}_{3}$ at high temperature. Although the heating and electrochemical processes are different in nature, the heating result supports the hypothesis that a solid solution of cubic $\mathrm{Na}_{2} \mathrm{TiO}_{3}$ and $\mathrm{TiO}$ phases could be formed in the $\mathrm{TiO}_{2} / \mathrm{C}$ electrode charged to $0.01 \mathrm{~V}$.

During sodiation, $\mathrm{TiO}_{2}$ was fully converted to $\mathrm{Na}_{2} \mathrm{Ti}^{\mathrm{II}} \mathrm{Ti}^{\mathrm{iV}} \mathrm{O}_{4}$. One may expect that $\mathrm{Na}_{2} \mathrm{Ti}^{\mathrm{II}} \mathrm{Ti}^{\mathrm{iV}} \mathrm{O}_{4}$ should also be fully converted to $\mathrm{TiO}_{2}$ during desodiation. However, the observed discharge capacity (approximately $260 \mathrm{~mA} \mathrm{~h} \mathrm{~g}^{-1}$ ) is lower than that the sodiation capacity at voltages below $0.4 \mathrm{~V}$. Therefore, the desodiation process is incomplete, which is also supported by the EDX analysis (ESI, $\dagger$ Table S2). Part of the $\mathrm{Na}_{2} \mathrm{Ti}^{\mathrm{II}} \mathrm{Ti}^{\mathrm{iV}} \mathrm{O}_{4}$ solid solution or its derivatives should be retained in the $\mathrm{TiO}_{2} / \mathrm{C}$ electrode discharged to $2.5 \mathrm{~V}$. Considering that only the TiO crystal phase was experimentally observed, the desodiation process may result in the formation of amorphous $\mathrm{Na}_{2} \mathrm{TiO}_{3}$ and crystalline TiO. In this case, the $\mathrm{TiO}_{2} / \mathrm{C}$ electrode discharged to $2.5 \mathrm{~V}$ should consist of amorphous $\mathrm{TiO}_{2}$, amorphous $\mathrm{Na}_{2} \mathrm{TiO}_{3}$, and crystalline TiO phases. This combination of the oxidation states of $\mathrm{Ti}$ is different from that described in the literature, where $\mathrm{Ti}^{3+}$ and $\mathrm{Ti}^{0}$ were found in the fully discharged and charged $\mathrm{TiO}_{2}$ electrodes, respectively. ${ }^{28}$ To further examine the oxidation states of $\mathrm{Ti}$ in the electrode charged to $0.01 \mathrm{~V}$ and discharged to $2.5 \mathrm{~V}$, X-ray photoelectron spectroscopy (XPS) analysis was performed. As shown in ESI, $\dagger$ Fig. S7, only $\mathrm{Ti}^{4+}$ and $\mathrm{Ti}^{2+}$ were present in these cases, instead of $\mathrm{Ti}^{3+}$ and $\mathrm{Ti}^{0}$. This supports our hypothesis of the formation of $\mathrm{Na}_{2} \mathrm{Ti}^{\mathrm{II}} \mathrm{Ti}^{\mathrm{iV}} \mathrm{O}_{4}$ solid solution during the sodiation process, and the mixture of amorphous $\mathrm{TiO}_{2}$, amorphous $\mathrm{Na}_{2} \mathrm{TiO}_{3}$, and cubic TiO during desodiation. 


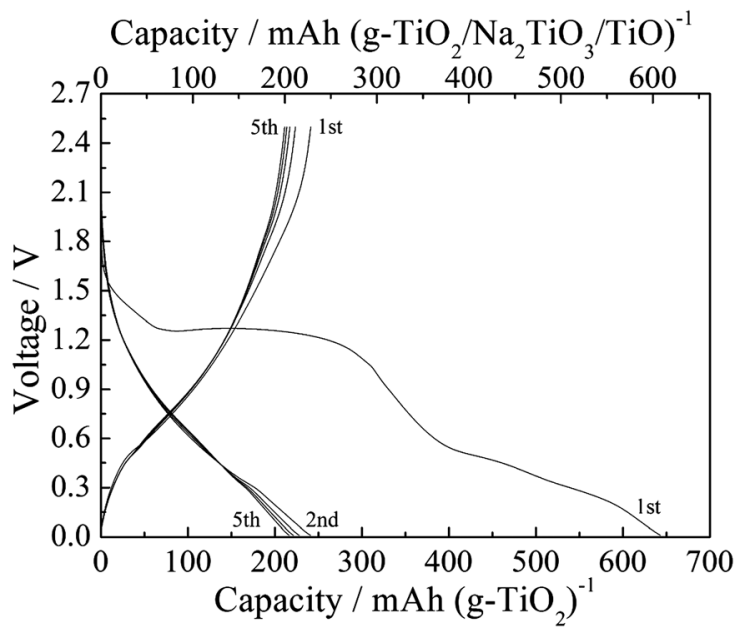

Fig. 6 Charge-discharge curves of the electrode with simulated oxide mixture $\left(\mathrm{TiO}_{2} / \mathrm{Na}_{2} \mathrm{TiO}_{3} / \mathrm{TiO}\right)$ at $20 \mathrm{~mA} \mathrm{~g}^{-1}$.

To verify that this mixture could act as the active electrode material, an electrode containing a simulated oxide mixture $\left(\mathrm{TiO}_{2} / \mathrm{Na}_{2} \mathrm{TiO}_{3} / \mathrm{TiO}\right.$ with a molar ratio of $\left.8: 1: 1\right)$ was fabricated and electrochemically tested under the same conditions. The simulated oxide mixture was prepared by ball-milling amorphous $\mathrm{TiO}_{2}$ (ca. $\left.10 \mathrm{~nm}\right)$, cubic $\mathrm{Na}_{2} \mathrm{TiO}_{3}(<100 \mathrm{~nm})$ and cubic $\mathrm{TiO}(<500 \mathrm{~nm})$ powders to form well-distributed $\mathrm{TiO}_{2} / \mathrm{Na}_{2} \mathrm{TiO}_{3} /$ TiO powders with an average particle size of less than $100 \mathrm{~nm}$. Fig. 6 shows the charge-discharge curves of the simulated oxide mixture electrode at $20 \mathrm{~mA} \mathrm{~g}^{-1}$. In the first charge process, there was no voltage plateau below $0.4 \mathrm{~V}$, and one plateau was present at about $1.3 \mathrm{~V}$ as a result of side reactions due to the nano-sized $\mathrm{TiO}_{2}$ particles. Hence, the sodiation process in the simulated oxide mixture electrode is different from that in the $\mathrm{TiO}_{2} / \mathrm{C}$ electrode. The first discharge capacity for the simulated oxide mixture electrode is $228 \mathrm{~mA} \mathrm{~h} \mathrm{~g}^{-1}$ when scaled for the total mass of active material $\left(\mathrm{TiO}_{2} / \mathrm{Na}_{2} \mathrm{TiO}_{3} / \mathrm{TiO}\right)$. When the weight of the active material was converted into that of $\mathrm{TiO}_{2}$ based on the molar mass of $\mathrm{Ti}$, the first discharge capacity became $241 \mathrm{~mA} \mathrm{~h} \mathrm{~g}^{-1}$, which is close to the value of the $\mathrm{TiO}_{2} / \mathrm{C}$ electrode (260 $\mathrm{mA} \mathrm{h} \mathrm{g}^{-1}$ scaled for $\mathrm{TiO}_{2} / \mathrm{C}$, Fig. 2a). In contrast, when only amorphous $\mathrm{TiO}_{2}$ was used as the active electrode material, the discharge capacity of the electrode was $112 \mathrm{~mA} \mathrm{~h} \mathrm{~g}^{-1}$ (ESI, $\dagger$ Fig. S8), a value much lower than that of the simulated oxide mixture electrode. Moreover, when only $\mathrm{Na}_{2} \mathrm{TiO}_{3}$ and TiO were used as the active electrode material, the discharge capacity per active material mass was less than $80 \mathrm{~mA} \mathrm{~h} \mathrm{\textrm {g } ^ { - 1 }}$ (ESI, $\dagger$ Fig. S9). Considering these data, the combination of crystalline $\mathrm{Na}_{2} \mathrm{TiO}_{3}$ and $\mathrm{TiO}$ in the amorphous $\mathrm{TiO}_{2}$ phase obviously improved the electrochemical sodiation-desodiation properties. Therefore, in addition to the confirmed cubic TiO phase, the speculated formation of amorphous $\mathrm{TiO}_{2}$ and $\mathrm{Na}_{2} \mathrm{TiO}_{3}$ phases in the electrode discharged to $2.5 \mathrm{~V}$ is quite reasonable.

According to the above analysis, the newly proposed sodiation and desodiation mechanism of anatase $\mathrm{TiO}_{2} / \mathrm{C}$ electrode is as follows:
(1) First charge process:

$$
2 \mathrm{TiO}_{2}+2 \mathrm{Na}^{+}+2 \mathrm{e}^{-} \rightarrow \mathrm{Na}_{2} \mathrm{Ti}^{\mathrm{II}} \mathrm{Ti}^{\mathrm{IV}} \mathrm{O}_{4}
$$

(2) First discharge process:

$$
5 \mathrm{Na}_{2} \mathrm{Ti}^{\mathrm{II}} \mathrm{Ti}^{\mathrm{IV}} \mathrm{O}_{4} \rightarrow 8 \mathrm{TiO}_{2}+\mathrm{Na}_{2} \mathrm{TiO}_{3}+\mathrm{TiO}+8 \mathrm{Na}^{+}+8 \mathrm{e}^{-}
$$

(3) Reversible reaction processes:

$$
8 \mathrm{TiO}_{2}+\mathrm{Na}_{2} \mathrm{TiO}_{3}+\mathrm{TiO}+8 \mathrm{Na}^{+}+8 \mathrm{e}^{-} \rightleftarrows 5 \mathrm{Na}_{2} \mathrm{Ti}^{\mathrm{II}} \mathrm{Ti}^{\mathrm{IV}} \mathrm{O}_{4}
$$

In the first charge process, $\mathrm{Na}$ ions react with anatase $\mathrm{TiO}_{2}$ to form a cubic $\mathrm{Na}_{2} \mathrm{Ti}^{\mathrm{II}} \mathrm{Ti}^{\cdot \mathrm{V}} \mathrm{O}_{4}$ solid solution, accompanied by some side reactions such as electrolyte reduction. In the following first discharge, the $\mathrm{Na}_{2} \mathrm{Ti}^{\mathrm{II}} \mathrm{Ti}^{\mathrm{IV}} \mathrm{O}_{4}$ solid solution is converted into a mixture of amorphous $\mathrm{TiO}_{2}$, amorphous $\mathrm{Na}_{2} \mathrm{TiO}_{3}$ and cubic TiO. In the subsequent cycles, the mixture reversibly reacts with $\mathrm{Na}$ ions as the active electrode material, causing the formation and dissolution of the $\mathrm{Na}_{2} \mathrm{Ti}^{\mathrm{II}} \mathrm{Ti}^{\mathrm{IV}} \mathrm{O}_{4}$ solid solution.

\section{Conclusions}

In summary, we investigated the sodiation and desodiation of an anatase $\mathrm{TiO}_{2} / \mathrm{C}$ negative electrode in an ionic liquid electrolyte at $90{ }^{\circ} \mathrm{C}$, and revealed a new sodiation-desodiation mechanism. A $\mathrm{Na}_{2} \mathrm{Ti}^{\mathrm{I}} \mathrm{Ti}^{\mathrm{IV}} \mathrm{O}_{4}$ solid solution was formed in the first sodiation process. During the desodiation process, the solid solution was converted reversibly into amorphous $\mathrm{TiO}_{2}$, amorphous $\mathrm{Na}_{2} \mathrm{TiO}_{3}$, and crystalline TiO, thereby providing a high reversible specific capacity of $c a .260 \mathrm{~mA} \mathrm{~h} \mathrm{~g}^{-1}$. The new active material, i.e., the composite of $\mathrm{TiO}_{2}, \mathrm{Na}_{2} \mathrm{TiO}_{3}$ and TiO, could provide key information for the design of new negative electrode materials based on anatase $\mathrm{TiO}_{2}$. We believe that the results shown here will give powerful insights for creating safer rechargeable sodium batteries with higher energy density.

\section{Acknowledgements}

This study was partly supported by the Advanced Low Carbon Technology Research and Development Program (ALCA, No. 3428) of the Japan Science and Technology Agency (JST) and the "Elements Strategy Initiative to Form Core Research Center" program of the Japanese Ministry of Education, Culture, Sports, Science and Technology (MEXT).

\section{Notes and references}

1 N. Yabuuchi, M. Kajiyama, J. Iwatate, H. Nishikawa, S. Hitomi, R. Okuyama, R. Usui, Y. Yamada and S. Komaba, Nat. Mater., 2012, 11, 512-517.

2 E. Hosono, T. Saito, J. Hoshino, M. Okubo, Y. Saito, D. NishioHamane, T. Kudo and H. S. Zhou, J. Power Sources, 2012, 217, 43-46.

3 J. Billaud, R. J. Clement, A. R. Armstrong, J. CanalesVazquez, P. Rozier, C. P. Grey and P. G. Bruce, J. Am. Chem. Soc., 2014, 136, 17243-17248. 
4 C. Y. Yu, J. S. Park, H. G. Jung, K. Y. Chung, D. Aurbach, Y. K. Sun and S. T. Myung, Energy Environ. Sci., 2015, 8, 2019-2026.

5 P. Barpanda, G. D. Liu, C. D. Ling, M. Tamaru, M. Avdeev, S. C. Chung, Y. Yamada and A. Yamada, Chem. Mater., 2013, 25, 3480-3487.

6 Z. L. Jian, L. Zhao, H. L. Pan, Y. S. Hu, H. Li, W. Chen and L. Q. Chen, Electrochem. Commun., 2012, 14, 86-89.

7 J. Kim, D. H. Seo, H. Kim, I. Park, J. K. Yoo, S. K. Jung, Y. U. Park, W. A. Goddard and K. Kang, Energy Environ. Sci., 2015, 8, 540-545.

8 L. Wu, X. H. Hu, J. F. Qian, F. Pei, F. Y. Wu, R. J. Mao, X. P. Ai, H. X. Yang and Y. L. Cao, Energy Environ. Sci., 2014, 7, 323-328.

9 J. W. Wang, X. H. Liu, S. X. Mao and J. Y. Huang, Nano Lett., 2012, 12, 5897-5902.

10 S. Komaba, W. Murata, T. Ishikawa, N. Yabuuchi, T. Ozeki, T. Nakayama, A. Ogata, K. Gotoh and K. Fujiwara, Adv. Funct. Mater., 2011, 21, 3859-3867.

11 H. Pan, X. Lu, X. Yu, Y.-S. Hu, H. Li, X.-Q. Yang and L. Chen, Adv. Energy Mater., 2013, 3, 1186-1194.

12 M. Shirpour, J. Cabana and M. Doeff, Energy Environ. Sci., 2013, 6, 2538-2547.

13 H. Xiong, M. D. Slater, M. Balasubramanian, C. S. Johnson and T. Rajh, J. Phys. Chem. Lett., 2011, 2, 2560-2565.

14 Y. Xu, E. M. Lotfabad, H. Wang, B. Farbod, Z. Xu, A. Kohandehghan and D. Mitlin, Chem. Commun., 2013, 49, 8973-8975.
15 K. T. Kim, G. Ali, K. Y. Chung, C. S. Yoon, H. Yashiro, Y. K. Sun, J. Lu, K. Amine and S. T. Myung, Nano Lett., 2014, 14, 416-422.

16 L. Wu, D. Buchholz, D. Bresser, L. Gomes Chagas and S. Passerini, J. Power Sources, 2014, 251, 379-385.

17 X. M. Yang, C. Wang, Y. C. Yang, Y. Zhang, X. N. Jia, J. Chen and X. B. Ji, J. Mater. Chem. A, 2015, 3, 8800-8807.

18 J. P. Huang, D. D. Yuan, H. Z. Zhang, Y. L. Cao, G. R. Li, H. X. Yang and X. P. Gao, RSC Adv., 2013, 3, 12593.

19 J. C. Perez-Flores, C. Baehtz, A. Kuhn and F. GarciaAlvarado, J. Mater. Chem. A, 2014, 2, 1825-1833.

20 H. Usui, S. Yoshioka, K. Wasada, M. Shimizu and H. Sakaguchi, ACS Appl. Mater. Interfaces, 2015, 7, 6567-6573.

21 C. S. Ding, T. Nohira and R. Hagiwara, J. Mater. Chem. A, 2015, 3, 20767-20771.

22 G. Sudant, E. Baudrin, D. Larcher and J. M. Tarascon, J. Mater. Chem., 2005, 15, 1263-1269.

23 R. van de Krol, A. Goossens and E. A. Meulenkamp, J. Electrochem. Soc., 1999, 146, 3150-3154.

24 R. J. Cava, D. W. Murphy, S. Zahurak, A. Santoro and R. S. Roth, J. Solid State Chem., 1984, 53, 64-75.

25 M. Wagemaker, W. J. H. Borghols and F. M. Mulder, J. Am. Chem. Soc., 2007, 129, 4323-4327.

26 M. Wagemaker, G. J. Kearley, A. A. van Well, H. Mutka and F. M. Mulder, J. Am. Chem. Soc., 2003, 125, 840-848.

27 A. A. Belak, Y. Z. Wang and A. Van der Ven, Chem. Mater., 2012, 24, 2894-2898.

28 L. M. Wu, D. Bresser, D. Buchholz, G. A. Giffin, C. R. Castro, A. Ochel and S. Passerini, Adv. Energy Mater., 2015, 5, 1401142. 